\title{
Anosmia in Case of COVID-19 Patients: Dilemmas Faced in Neurotrauma Care
}

\author{
Luis Rafael Moscote-Salazar ${ }^{1,2}$ Tariq Janjua ${ }^{3}$ Pilar Bosque-Varela ${ }^{1} \quad$ Amit Agrawal $^{4}$
}

1 Paracelsus Medical University, Salzburg, Austria

${ }^{2}$ Department of Neurosurgery, Center of Biomedical Research, University of Cartagena, Cartagena de Indias, Colombia

${ }^{3}$ Regions Hospital, Saint Paul, Minnesota, United States

${ }^{4}$ Department of Neurosurgery, All India Institute of Medical Sciences, Bhopal, India

Indian J Neurotrauma 2023;20:55-56.

The new coronavirus (COVID-19/SARS-CoV-2) and the associated pandemic is continuously presenting new challenges, and with a growing body of evidence, multiple clinical settings have been created for the neurosurgeons. ${ }^{1}$ Inflammation and demyelination are two pathobiological mechanisms resulting from the entry of the SARS-CoV-2 into the central nervous system (CNS). ${ }^{2,3}$ Although cranial nerve involvement was not mentioned in the first reports, in the weeks after the pandemic, it was clinically characterized that patients with COVID-19 can develop anosmia. ${ }^{4,5}$ This demonstrates the neuroinvasive potential of this unusual pathogen. ${ }^{6}$

Studies suggest that approximately 25 to $30 \%$ of patients with severe cranial neurotrauma develop anosmia. ${ }^{7}$ The etiologic mechanism of posttraumatic anosmia is a determining factor in recovery. ${ }^{8}$ The presence of anosmia in patients with traumatic brain injury (TBI) and concomitant history of COVID-19/SARS-CoV-2 can present a diagnostic challenge. It becomes more challenging as many pathologies, that is, inflammatory, neurodegenerative pathologies, medications, and viral infections can also cause anosmia. ${ }^{7}$ Multiple reports mentioned recovery in the first weeks after the onset of symptoms. ${ }^{9,10}$ It has been well-established that different types of Coronaviruses produce post-infection anosmia in humans. ${ }^{11}$ It is important to remember that the anosmia associated with SARS-CoV-2 is transient and shall recover during the recovery phase. ${ }^{12}$ During the clinical assessment of TBI patients, we must be alert to the possibility that the patients with anosmia in the background of history of trauma may be contaminated with SARS-CoV-2. History and further evaluation should include a high-index of suspicion. In addition, we suggest the there is a need to

article published online September 22, 2021
DOI https://doi.org/ 10.1055/s-0041-1729351. ISSN 0973-0508.
Address for correspondence Luis Rafael Moscote-Salazar, MD, Department of Neurosurgery, University of Cartagena, Cra. 50 \#24120, Cartagena de Indias, Colombia (e-mail: rafaelmoscote21@gmail.com).

document in order to characterize the structural injuries as well as share the global experience, thereby understanding the clinical and imaging characteristics associated with SARS-CoV-2 infection in the background of history of TBI.

Funding
None.

Conflict of Interest

P.B.V. received a predoctoral fellowship from the Fundacion Alfonso Martin Escudero (Spain). Rest authors declare no conflict of interest.

\section{References}

1 Guan WJ, Ni ZY, Hu Y, et al. China Medical Treatment Expert Group for Covid-19. Clinical characteristics of Coronavirus disease 2019 in China. N Engl J Med 2020;382(18):1708-1720

2 Zanin L, Saraceno G, Panciani PP, et al. SARS-CoV-2 can induce brain and spine demyelinating lesions. Acta Neurochir (Wien) 2020;162(07):1491-1494

3 De Santis G. SARS-CoV-2: A new virus but a familiar inflammation brain pattern. Brain Behav Immun 2020;S0889-1591(20): 30676-30670

4 Gautier JF, Ravussin Y. A new symptom of COVID-19: loss of taste and smell. Obesity (Silver Spring) 2020;28(05):848

5 Zhang Q, Shan KS, Abdollahi S, Nace T. Anosmia and ageusia as the only indicators of Coronavirus disease 2019 (COVID-19). Cureus 2020;12(05):e7918-e7918

6 Conde Cardona G, Quintana Pájaro LD, Quintero Marzola ID, Ramos Villegas Y, Moscote Salazar LR. Neurotropism of SARS$\mathrm{CoV}$ 2: mechanisms and manifestations. J Neurol Sci 2020; 412:116824-116824

7 Costanzo RM, Reiter RJ, Yelverton JCSmell and taste. In: Zasler ND, Katz DI, Zafonte RD, eds. Brain Injury Medicine. Demos. New York, NY: Springer Publishing2012:794-808

(c) 2021. The Author(s).

This is an open access article published by Thieme under the terms of the Creative Commons Attribution License, permitting unrestricted use, distribution, and reproduction so long as the original work is properly cited. (https://creativecommons.org/licenses/by/4.0/)

Thieme Medical and Scientific Publishers Pvt. Ltd., A-12, 2nd Floor, Sector 2, Noida-201301 UP, India 


\section{Letter to the Editor}

8 Howell J, Costanzo RM, Reiter ER. Head trauma and olfactory function. World J Otorhinolaryngol Head Neck Surg 2018;4(01): 39-45

9 Vaira LA, Deiana G, Fois AG, et al. Objective evaluation of anosmia and ageusia in COVID-19 patients: single-center experience on 72 cases. Head Neck 2020;42(06):1252-1258

10 Yan CH, Faraji F, Prajapati DP, Boone CE, DeConde AS. Association of chemosensory dysfunction and COVID-19 in patients presenting with influenza-like symptoms. Int Forum Allergy Rhinol 2020

11 Suzuki M, Saito K, Min WP, et al. Identification of viruses in patients with postviral olfactory dysfunction. Laryngoscope 2007;117(02):272-277

12 Marinosci A, Landis BN, Calmy A. Possible link between anosmia and COVID-19: sniffing out the truth. Eur Arch Otorhinolaryngol 2020;277(07):2149-2150 